Keywords: Plutonium, Fluoride, Dissolution

Retention: Permanent

\title{
Dissolution of 3013-DE Sample 10-16
}

K. M. L. Taylor-Pashow

May 2011

Savannah River National Laboratory Savannah River Nuclear Solutions Aiken, SC 29808

Prepared for the U.S. Department of Energy under contract number DE-AC09-08SR22470.

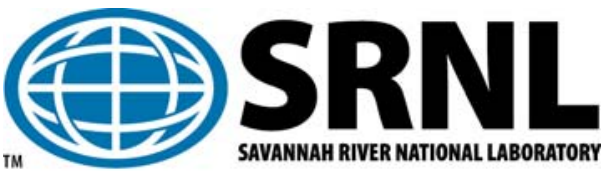


SRNL-STI-2011-00222

Revision 0

\section{DISCLAIMER}

This work was prepared under an agreement with and funded by the U.S. Government. Neither the U.S. Government or its employees, nor any of its contractors, subcontractors or their employees, makes any express or implied:

1. warranty or assumes any legal liability for the accuracy, completeness, or for the use or results of such use of any information, product, or process disclosed; or

2. representation that such use or results of such use would not infringe privately owned rights; or

3. endorsement or recommendation of any specifically identified commercial product, process, or service.

Any views and opinions of authors expressed in this work do not necessarily state or reflect those of the United States Government, or its contractors, or subcontractors.

\section{Printed in the United States of America \\ Prepared for \\ U.S. Department of Energy}




\section{REVIEWS AND APPROVALS}

AUTHOR:

K. M. L. Taylor-Pashow, Separations and Actinide Science Programs

Date

TECHNICAL REVIEW:

G. F. Kessinger, Separations and Actinide Science Programs

Date

A. T. Masterson, HB-Line Engineering

Date

APPROVAL:

S. D. Fink, Manager

Date

Separations and Actinide Science Programs

S. L. Marra, Manager

Date

Environmental \& Chemical Process Technology Research Programs

K. P. Burrows, Manager

Date

HB-Line Engineering 
SRNL-STI-2011-00222

Revision 0

\section{EXECUTIVE SUMMARY}

The HB-Line Facility has a long-term mission to dissolve and disposition legacy fissile materials. HB-Line dissolves plutonium dioxide $\left(\mathrm{PuO}_{2}\right)$ from K-Area parting support of the 3013 Destructive Examination (DE) program. ${ }^{\mathrm{a}}$ The $\mathrm{PuO}_{2}$-bearing solids originate from a variety of unit operations and processing facilities, but all of the material is assumed to be high-fired (i.e., calcined in air for a minimum of two hours at $\geq 750^{\circ} \mathrm{C}$ ).

The Savannah River National Laboratory (SRNL) conducted dissolution flowsheet studies on 3013 DE Sample 10-16 (can R610826), which contains weapons-grade plutonium (Pu) as the fissile material. The dissolution flowsheet study was performed for 4 hours at $108{ }^{\circ} \mathrm{C}$ on unwashed material using $12 \mathrm{M}$ nitric acid $\left(\mathrm{HNO}_{3}\right)$ containing $0.20 \mathrm{M}$ potassium fluoride $(\mathrm{KF})$. After 4 hours at $108{ }^{\circ} \mathrm{C}$, the ${ }^{239} \mathrm{Pu}$ Equivalent concentration was $32.5 \mathrm{~g} / \mathrm{L}$ (gamma, 5.0\% uncertainty). The insoluble residue comprised $9.88 \mathrm{wt} \%$ of the initial bulk weight, and contained $5.31-5.95 \mathrm{wt} \%$ of the initial $\mathrm{Pu}$. The residue contained $\mathrm{Pu}$ in the highest concentration, followed by tungsten (W).

Analyses detected $2,770 \mathrm{mg} / \mathrm{L}$ chloride $\left(\mathrm{Cl}^{-}\right)$in the final dissolver solution $(3.28 \mathrm{wt} \%)$, which is significantly lower than the amount of $\mathrm{Cl}^{-}$detected by prompt gamma $(9.86 \mathrm{wt} \%)$ and the 3013 DE Surveillance program (14.7 wt \%). A low bias in chloride measurement is anticipated due to volatilization during the experiment. Gas generation studies found approximately $60 \mathrm{~mL}$ of gas per gram of sample produced during the first 30 minutes of dissolution. Little to no gas was produced after the first 30 minutes. Hydrogen gas $\left(\mathrm{H}_{2}\right)$ was not detected in the sample. Based on detection limits and accounting for dilution, the generated gas contained $<0.12 \mathrm{vol} \% \mathrm{H}_{2}$, which is well below the $4.0 \mathrm{vol} \%$ flammability limit for $\mathrm{H}_{2}$ in air.

Filtration of the dissolver solution occurred readily. When aluminum nitrate nonahydrate (ANN) was added to the filtered dissolver solution at a 3:1 Al:F molar ratio, and stored at room temperature for 24 hours, the solution filtered approximately 6 times slower than when filtered 30 minutes after ANN addition, requiring 6 minutes to complete compared to 55 seconds for the first filtration. It is likely that the ambient-temperature solubility for ANN was exceeded.

A 4-hour dissolution time at a temperature of $108{ }^{\circ} \mathrm{C}$ in $12 \mathrm{M} \mathrm{HNO}_{3} / 0.2 \mathrm{M} \mathrm{KF}$ is recommended for dissolution of this material.

\footnotetext{
${ }^{a}$ Recently, DOE issued guidance suspending the dissolution program. This flowsheet, in progress at the time of that decision, is being documented for later use.
} 


\section{TABLE OF CONTENTS}

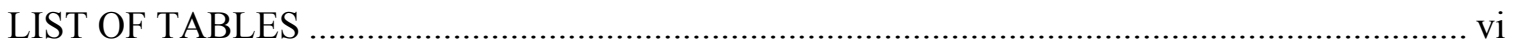

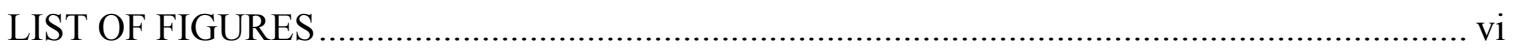

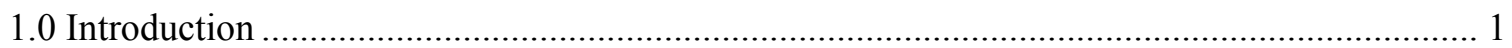

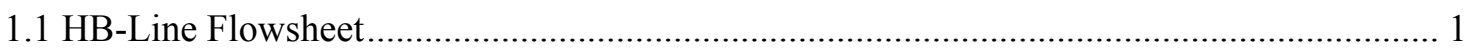

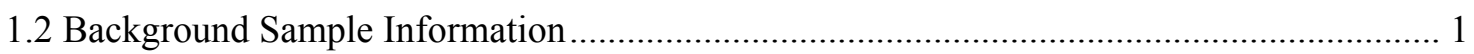

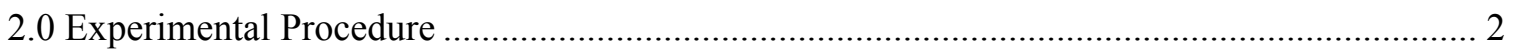

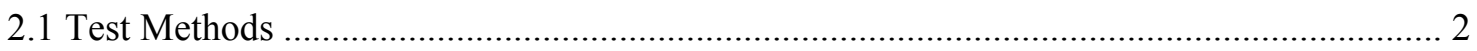

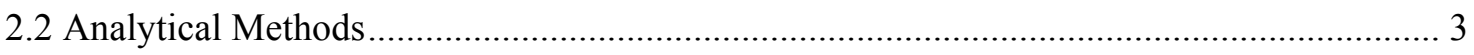

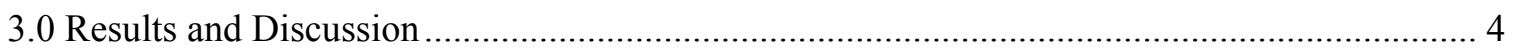

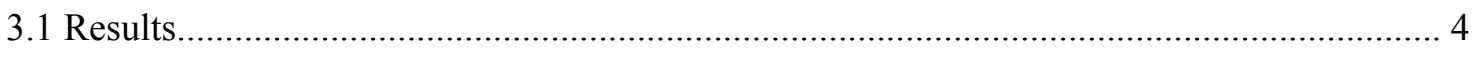

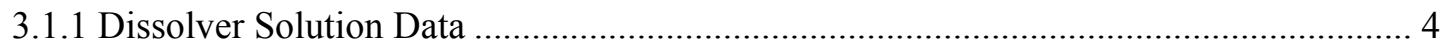

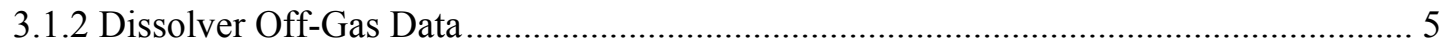

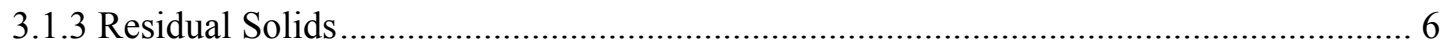

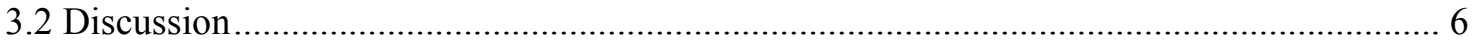

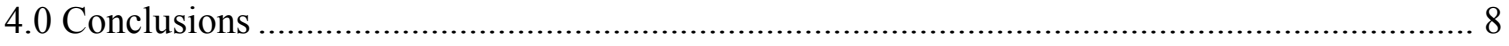

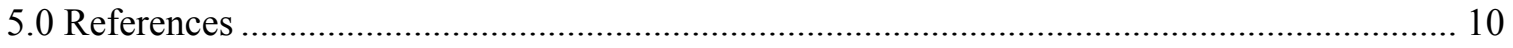

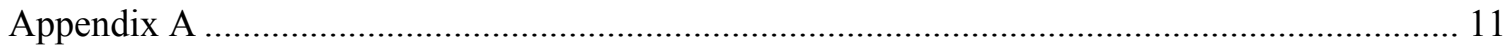

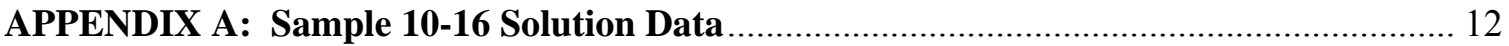

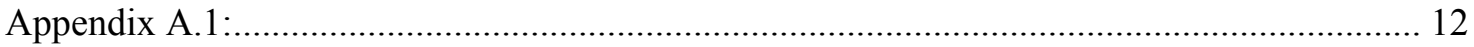

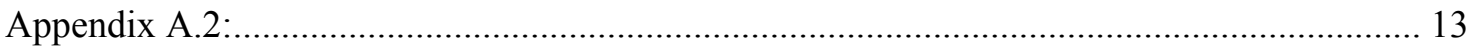




\section{LIST OF TABLES}

Table 1-1. Prompt Gamma Data for Parent 3013 Cans for Sample 10-16................................... 1

Table 1-2. Sample 10-16 Characterization Data from 3013 DE Surveillance Program................ 2

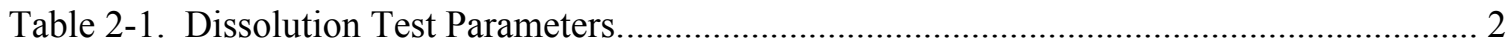

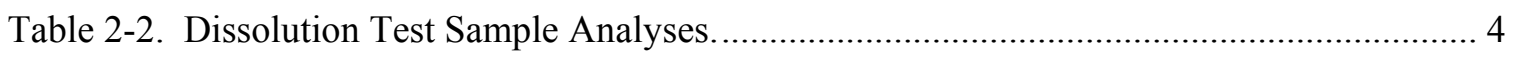

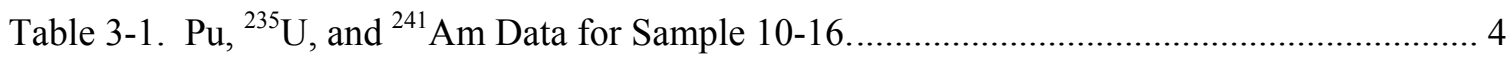

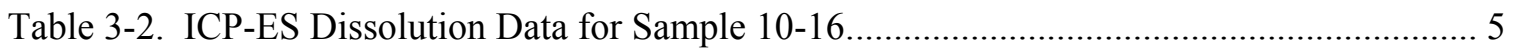

Table 3-3. Other Data for Sample 10-16 (Post Dissolution). ..................................................... 5

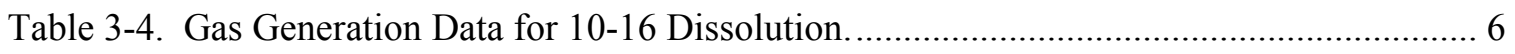

Table 3-5. Concentration Data from Residue Dissolution using $\mathrm{Na}_{2} \mathrm{O}_{2}$ Fusion........................... 6

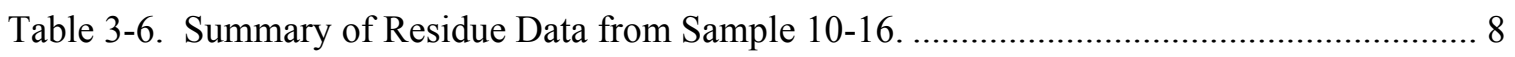

Table 4-1. Elements/Anions in DE Sample 10-16 Dissolver Product Solution. ............................ 9

Table 4-2. Flowsheet Test Summary for DE Sample 10-16 ................................................... 9

\section{LIST OF FIGURES}

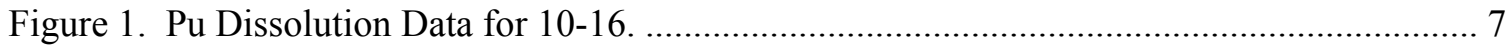




\section{LIST OF ABBREVIATIONS}

$\begin{array}{ll}\text { ANN } & \text { aluminum nitrate nonahydrate } \\ \text { DE } & \text { destructive examination } \\ \text { GC } & \text { gas chromatography } \\ \text { IC } & \text { ion chromatography } \\ \text { ICP-ES } & \text { inductively coupled plasma - emission spectroscopy } \\ \text { ICP-MS } & \text { inductively coupled plasma - mass spectroscopy } \\ \text { MC\&A } & \text { material control and accountability } \\ \text { rpm } & \text { revolutions per minute } \\ \text { SRNL } & \text { Savannah River National Laboratory } \\ \text { TGA-MS } & \text { thermogravimetric analysis - mass spectroscopy } \\ \text { XRD } & \text { X-ray diffraction }\end{array}$


SRNL-STI-2011-00222

Revision 0

\subsection{Introduction}

\subsection{HB-Line Flowsheet}

The HB-Line Facility has a long-term mission to dissolve fissile materials and disposition them. HB-Line dissolves $\mathrm{PuO}_{2}$ coming from K-Area in support of the $3013 \mathrm{DE}$ program. (DOE recently suspended such processing in HB-Line; SRNL is documenting this study in progress at the time of that program decision.) The $\mathrm{PuO}_{2}$ is from various unit operations and processing facilities throughout the DOE complex, but all of the material has been calcined for a minimum of two hours at $\geq 750{ }^{\circ} \mathrm{C}$, in accordance with the requirements of the Department of Energy standard for the packaging and long-term storage of plutonium materials (DOE-STD-3013). ${ }^{[1]}$

To support the dissolution of these materials in HB-Line, SRNL conducted testing to validate an existing dissolution flowsheet. The original objective of flowsheet testing was to dissolve 3013 DE materials to $\sim 70 \mathrm{~g} / \mathrm{L} \mathrm{Pu}$ with less than $5 \%$ of the $\mathrm{Pu}$ remaining in the solid residue. ${ }^{[2]}$ As a result, the recommended flowsheet included the use of $12 \mathrm{M}$ nitric acid $\left(\mathrm{HNO}_{3}\right)$ and $0.2 \mathrm{M}$ potassium fluoride (KF) at $112-114{ }^{\circ} \mathrm{C}$ for 12 hours. The flowsheet requirements were modified to $12 \mathrm{M} \mathrm{HNO}_{3}$ and $0.2 \mathrm{M} \mathrm{KF}$ for 12 hours at $108{ }^{\circ} \mathrm{C}$ to produce a final concentration containing $\sim 47 \mathrm{~g} / \mathrm{L}$ of dissolved fissile material. ${ }^{[3]}$ The current objective is to produce a product with a $\mathrm{Pu}$ concentration of 30-35 g/L while minimizing the corrosion impact to the dissolver and associated equipment. ${ }^{[4]}$ To meet this objective, the dissolution protocol was further modified to dissolve in $12 \mathrm{M} \mathrm{HNO}_{3}$ containing $0.20 \mathrm{M} \mathrm{KF}$ at $108{ }^{\circ} \mathrm{C}$ for 4 hours.

The primary objectives of the present study are to test the flowsheet for dissolution efficacy, identify and characterize gases generated during the dissolution process, and to characterize the behavior of the dissolver solution after the addition of ANN (results of an earlier investigation indicate the potential for precipitation subsequent to $\mathrm{ANN}$ addition). ${ }^{[5]}$

\subsection{Background Sample Information}

Dissolution flowsheet studies were performed on Sample 10-16, Vial B366 (Source Item R610826). Prompt gamma analyses of the material measured in K-Area are listed in Table 1-1; prompt gamma count times are typically 60 minutes.

Table 1-1. Prompt Gamma Data for Parent 3013 Cans for Sample 10-16.

\begin{tabular}{|c|c|c|c|}
\hline 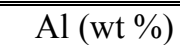 & ND & $\mathrm{Mg}(\mathrm{wt} \%)$ & 1.71 \\
\hline $\mathrm{Be}(\mathrm{wt} \%)$ & 0.054 & $\mathrm{Na}(\mathrm{wt} \%)$ & 2.97 \\
\hline $\mathrm{Cl}(\mathrm{wt} \%)$ & 9.86 & K (wt \%) & 4.22 \\
\hline $\mathrm{F}(\mathrm{wt} \%)$ & 0.333 & & \\
\hline \multicolumn{4}{|c|}{$\mathrm{ND}=$ not detected } \\
\hline
\end{tabular}

Prior analysis of the samples for the DE surveillance program yielded the results in Table 1-2. 
Table 1-2. Sample 10-16 Characterization Data from 3013 DE Surveillance Program.

\begin{tabular}{|c|c|c|c|}
\hline$\frac{\text { Major Compound(s) } \mathbf{X R D}^{[6]}}{\text { Minor Compound(s) XRD }}$ & \multicolumn{3}{|l|}{$\mathrm{PuO}_{2}$} \\
\hline \multicolumn{4}{|l|}{ ICPES Data: ${ }^{[7]}$} \\
\hline $\mathrm{Ag}(\mu \mathrm{g} / \mathrm{g})$ & $<119$ & $\mathrm{Mg}(\mu \mathrm{g} / \mathrm{g})$ & 12,800 \\
\hline $\mathrm{Al}(\mu \mathrm{g} / \mathrm{g})$ & 364 & $\mathrm{Mn}(\mu \mathrm{g} / \mathrm{g})$ & 192 \\
\hline $\mathrm{Ba}(\mu \mathrm{g} / \mathrm{g})$ & $<94.8$ & Mo $(\mu \mathrm{g} / \mathrm{g})$ & $<201$ \\
\hline $\mathrm{Be}(\mu \mathrm{g} / \mathrm{g})$ & 1305 & $\mathrm{Na}(\mu \mathrm{g} / \mathrm{g})$ & 42,400 \\
\hline $\mathrm{Ca}(\mu \mathrm{g} / \mathrm{g})$ & 5,865 & $\mathrm{Ni}(\mu \mathrm{g} / \mathrm{g})$ & 8,960 \\
\hline $\mathrm{Cd}(\mu \mathrm{g} / \mathrm{g})$ & $<124$ & $\mathrm{~Pb}(\mu \mathrm{g} / \mathrm{g})$ & $<467$ \\
\hline $\mathrm{Cr}(\mu \mathrm{g} / \mathrm{g})$ & 870 & $\mathrm{Sn}(\mu \mathrm{g} / \mathrm{g})$ & $<551$ \\
\hline $\mathrm{Cu}(\mu \mathrm{g} / \mathrm{g})$ & $<792$ & $\mathrm{Ti}(\mu \mathrm{g} / \mathrm{g})$ & 137 \\
\hline $\mathrm{Fe}(\mu \mathrm{g} / \mathrm{g})$ & 3,685 & $\mathrm{U}(\mu \mathrm{g} / \mathrm{g})$ & $<9,710$ \\
\hline $\mathrm{K}(\mu \mathrm{g} / \mathrm{g})$ & 65,250 & $\mathrm{Zn}(\mu \mathrm{g} / \mathrm{g})$ & 381 \\
\hline $\mathrm{La}(\mu \mathrm{g} / \mathrm{g})$ & $<103$ & $\mathrm{Zr}(\mu \mathrm{g} / \mathrm{g})$ & $<142$ \\
\hline \multicolumn{4}{|l|}{ IC Data: ${ }^{[8]}$} \\
\hline $\mathrm{F}^{-}(\mu \mathrm{g} / \mathrm{g})$ & $<301$ & $\mathrm{PO}_{4}{ }^{3-}(\mu \mathrm{g} / \mathrm{g})$ & $<150$ \\
\hline $\mathrm{Cl}^{-}(\mu \mathrm{g} / \mathrm{g})$ & 146,500 & $\mathrm{SO}_{4}^{2-}(\mu \mathrm{g} / \mathrm{g})$ & 1,145 \\
\hline $\mathrm{NO}_{3}^{-}(\mu \mathrm{g} / \mathrm{g})$ & 80 & & \\
\hline
\end{tabular}

\subsection{Experimental Procedure}

\subsection{Test Methods}

A single dissolution test was performed. The sample was not washed (to remove $\mathrm{Cl}^{-}$) prior to testing. The dissolution test used $12 \mathrm{M} \mathrm{HNO}_{3}$ and $0.2 \mathrm{M} \mathrm{KF}$ at $108{ }^{\circ} \mathrm{C}$ for 4 hours. A list of the process conditions is contained in Table $2-1$.

Table 2-1. Dissolution Test Parameters.

\begin{tabular}{|c|c|c|c|c|c|c|}
\hline DE Sample & $\begin{array}{c}\mathbf{H N O}_{3} \\
(\mathrm{M})\end{array}$ & $\begin{array}{c}\text { KF } \\
\mathbf{( M )}\end{array}$ & $\begin{array}{c}\text { Liquid } \\
\text { Vol. (mL) }\end{array}$ & $\begin{array}{c}\text { Sample } \\
\text { wt (g) }\end{array}$ & $\begin{array}{c}\text { Fissile } \\
\text { (g)* }\end{array}$ & Vial \# \\
\hline $10-16$ & 12 & 0.2 & 100 & 7.590 & 4.00 & B-366 \\
\hline \multicolumn{7}{|l|}{ * Based on material control and accountability (MC\&A) data. } \\
\hline
\end{tabular}

The dissolution was performed using a borosilicate flask fitted with a reflux condenser to minimize evaporative losses. The total volume of the flask and the condenser is $180 \mathrm{~mL}$. Operationally, the dissolution test was performed as follows. The amount of bulk sample specified in Table 2-1 was added to the empty test vessel. The dissolver solution was added on top of the solids along with a stir bar. The dissolver head space was purged with argon (Ar) by connecting the vessel to the Ar supply plumbed into the glovebox. After purging, the Ar gas service was disconnected and an empty $1-\mathrm{L}$ gas collection bag was connected to the apparatus. The dissolver was then sealed to isolate it from the glovebox atmosphere.

The hot plate was turned on and set to control the vessel liquid temperature at $108^{\circ} \mathrm{C}$. The stirrer was turned on at $250 \mathrm{rpm}$ (revolutions per minute). The temperature of the system reached $108{ }^{\circ} \mathrm{C}$ within 15 minutes. Thirty minutes after reaching temperature the first gas collection bag was removed and an empty gas collection bag was attached to the system. The volume of gas collected was measured by water displacement, and a sample of the gas was collected for gas 
chromatography (GC) analysis. To obtain a sample of gas for GC, the gas collection bag was connected to a $25-\mathrm{mL}$ gas sample bulb that had previously been purged with Ar and evacuated. The gas bag was then opened to the sample bulb and the sample was drawn into the gas sample bulb. After the first 30 minutes no additional gas generation was observed. The second gas collection bag was left on for the remainder of the dissolution to maintain a closed system, although no additional gas was being produced.

After 1 hour at $108{ }^{\circ} \mathrm{C}$, the first liquid sample was removed. Five minutes prior to each sampling event (at 1, 2, 3, and 4 hours) the stirring was stopped to allow any solids to settle. Aliquots $(0.5 \mathrm{~mL})$ were then removed and diluted with an additional $0.5 \mathrm{~mL}$ of $12 \mathrm{M} \mathrm{HNO}_{3} / 0.2 \mathrm{M} \mathrm{KF}$ solution. Stirring was resumed immediately after sampling.

After 4 hours at $108{ }^{\circ} \mathrm{C}$, the heating and stirring were stopped and the solution was allowed to cool. After cooling to approximately $50{ }^{\circ} \mathrm{C}$, the 4-hour samples were removed, and the solution was then filtered through a 5-micron filter paper; $92 \mathrm{~mL}$ of filtrate was collected. The solids on the filter were dried in air for 5 days and weighed.

The filtrate $(92 \mathrm{~mL})$ was combined with $26 \mathrm{~mL}$ of $2.1 \mathrm{M}$ ANN. Thirty minutes after the addition of ANN to the dissolver solution, the solution was filtered through a 5-micron filter paper. Filtration was rapid, completing in less than one minute. Twenty-four hours after the addition of ANN to the dissolver solution, the solution was filtered again through a 5-micron filter paper. The solution filtered about 6 times slower than when filtered 30 minutes after ANN addition, requiring 6 minutes to complete.

The filter paper containing the residue from the first filtration (before ANN addition) was placed in a zirconium $(\mathrm{Zr})$ metal crucible. The crucible was then heated at $600{ }^{\circ} \mathrm{C}$ in a muffle furnace for 15 minutes to combust the filter paper. After cooling the crucible was reweighed to determine the mass of the residue $(0.4489 \mathrm{~g})$. Then, $3.7326 \mathrm{~g}$ of sodium peroxide $\left(\mathrm{Na}_{2} \mathrm{O}_{2}\right)$ was added to the crucible. The crucible and contents were heated to $700{ }^{\circ} \mathrm{C}$ in a muffle furnace and held at temperature for 57 minutes. After the crucible cooled, aliquots $(\sim 15 \mathrm{~mL})$ of $4 \mathrm{M} \mathrm{HNO}_{3}$ were added to the crucible to dissolve the residue. After each addition of $4 \mathrm{M} \mathrm{HNO}_{3}$ the contents of the crucible were decanted and filtered through a 5-micron filter paper. After all the residue had been dissolved and filtered, the solution volume was measured and samples were removed for gamma scan, ICP-MS, and ICP-ES analyses. The final volume of recovered solution was $43 \mathrm{~mL}$. After drying in air for 4 days a small amount (0.2085 g) of light colored solid was observed on the filter paper. The solid was not analyzed.

\subsection{Analytical Methods}

Table 2-2 is a tabulation of the samples collected during the experiment and submitted for analysis. 
Table 2-2. Dissolution Test Sample Analyses.

\begin{tabular}{|c|l||}
\hline $\begin{array}{c}\text { Total Time at } \\
\mathbf{1 0 8}{ }^{\circ} \mathbf{C}\end{array}$ & Sample Analyses \\
\hline $30 \mathrm{~min}$ & Gas: generation volume; GC \\
\hline $1 \mathrm{~h}$ & Liquid: ICP-MS, gamma spectroscopy \\
\hline $2 \mathrm{~h}$ & Liquid: ICP-MS, gamma spectroscopy \\
\hline $3 \mathrm{~h}$ & Liquid: ICP-MS, gamma spectroscopy \\
\hline $4 \mathrm{~h}$ & Liquid: ICP-MS, gamma spectroscopy, ICP-ES, IC anions, total acid, free acid \\
\hline Residue Fusion & Liquid: ICP-MS, gamma spectroscopy, ICP-ES \\
\hline GC = gas chromatography \\
ICP-MS = inductively coupled plasma - mass spectroscopy \\
ICP-ES = inductively coupled plasma - emission spectroscopy \\
IC = anion concentrations using ion chromatography \\
All samples for ICP-MS and gamma spectroscopy (except residue fusion samples) were diluted by a \\
factor of 2 prior to analysis. \\
\hline \hline
\end{tabular}

\subsection{Results and Discussion}

\subsection{Results}

\subsubsection{Dissolver Solution Data}

The data for samples collected at 1, 2, 3, and 4 hours for analyses by ICP-MS and gamma spectroscopy are provided in Appendix A along with notations regarding measurement uncertainty. The actinide concentration results are shown in Table 3-1, ICP-ES results are shown in Table 3-2, and other liquid sample results are shown in Table 3-3.

Table 3-1. Pu, ${ }^{235} \mathrm{U}$, and ${ }^{241} \mathrm{Am}$ Data for Sample 10-16.

\begin{tabular}{|c|c|c|c|c|}
\hline Analysis & $1 \mathrm{~h}(\mathrm{~g} / \mathrm{L})$ & $2 \mathrm{~h}(\mathrm{~g} / \mathrm{L})$ & $3 \mathrm{~h}(\mathrm{~g} / \mathrm{L})$ & $4 \mathrm{~h} *(\mathrm{~g} / \mathrm{L})$ \\
\hline${ }^{239} \mathrm{Pu}$ (gamma) & 24.5 & 24.1 & 23.8 & 30.6 \\
\hline${ }^{239} \mathrm{Pu}$ (ICPMS) & 26.2 & 26.2 & 26.6 & 31.8 \\
\hline${ }^{239} \mathrm{Pu}+{ }^{240} \mathrm{Pu}($ gamma $){ }^{\#}$ & 26.0 & 25.6 & 25.3 & 32.5 \\
\hline${ }^{239} \mathrm{Pu}+{ }^{240} \mathrm{Pu}(\mathrm{ICPMS})$ & 27.7 & 27.8 & 28.3 & 33.7 \\
\hline${ }^{235} \mathrm{U}(\mathrm{ICPMS})$ & 0.061 & 0.077 & 0.072 & 0.071 \\
\hline${ }^{241} \mathrm{Am}$ (gamma) & 0.066 & 0.067 & 0.067 & 0.086 \\
\hline Eq. ${ }^{239} \mathrm{Pu}(\mathrm{ICPMS})^{\dagger}$ & 27.8 & 27.9 & 28.3 & 33.7 \\
\hline \multicolumn{5}{|c|}{$\begin{array}{l}\text { * Final solution volume }=92 \mathrm{~mL} \\
{ }^{*} \text { Calculated using gamma }{ }^{239} \mathrm{Pu} \text { results, with ICPMS determined isotopic ratio. } \\
{ }^{\dagger} \mathrm{Eq}^{239} \mathrm{Pu}=\text { Total } \mathrm{Pu}+0.65 \mathrm{x}{ }^{235} \mathrm{U} \\
\text { ICPMS uncertainty }= \pm 20 \% \\
\text { Gamma uncertainty }= \pm 5.0 \%\end{array}$} \\
\hline
\end{tabular}


Table 3-2. ICP-ES Dissolution Data for Sample 10-16.

\begin{tabular}{|c|c|c|c|}
\hline $\begin{array}{l}\text { Analyte } \\
\text { LIMS \# }\end{array}$ & $\begin{array}{c}\text { Post-Dissolution (4 h) } \\
300282331\end{array}$ & $\begin{array}{c}\text { Calculated Based on } \\
\text { Table } 1-2^{*}\end{array}$ & $\begin{array}{c}\mathrm{Na}_{2} \mathrm{O}_{2} \text { Fusion } \\
300282711\end{array}$ \\
\hline $\mathrm{Ag}(\mathrm{mg} / \mathrm{L})$ & $<1.07$ & $<9.03$ & $<1.07$ \\
\hline $\mathrm{Al}(\mathrm{mg} / \mathrm{L})$ & 155 & 27.6 & 139 \\
\hline $\mathrm{Ba}(\mathrm{mg} / \mathrm{L})$ & 4.98 & $<7.20$ & 8.95 \\
\hline $\mathrm{Be}(\mathrm{mg} / \mathrm{L})$ & 118 & 99.1 & 5.64 \\
\hline $\mathrm{Ca}(\mathrm{mg} / \mathrm{L})$ & 400 & 445 & 104 \\
\hline $\mathrm{Cd}(\mathrm{mg} / \mathrm{L})$ & 4.37 & $<9.37$ & $<0.64$ \\
\hline $\mathrm{Cr}(\mathrm{mg} / \mathrm{L})$ & 66 & 66 & 338 \\
\hline $\mathrm{Cu}(\mathrm{mg} / \mathrm{L})$ & 144 & $<60.1$ & 9.08 \\
\hline $\mathrm{Fe}(\mathrm{mg} / \mathrm{L})$ & 298 & 280 & 136 \\
\hline $\mathrm{K}(\mathrm{mg} / \mathrm{L})$ & $13100^{\wedge}$ & $12800^{\circ}$ & 139 \\
\hline $\mathrm{La}(\mathrm{mg} / \mathrm{L})$ & $<0.32$ & $<7.78$ & $<0.5$ \\
\hline $\mathrm{Mg}(\mathrm{mg} / \mathrm{L})$ & 1110 & 972 & 221 \\
\hline $\mathrm{Mn}(\mathrm{mg} / \mathrm{L})$ & 20.2 & 14.6 & 2.57 \\
\hline Mo $(\mathrm{mg} / \mathrm{L})$ & $<2.14$ & $<15.2$ & 8.54 \\
\hline $\mathrm{Na}(\mathrm{mg} / \mathrm{L})$ & 3180 & 3220 & $43600^{\dagger}$ \\
\hline $\mathrm{Ni}(\mathrm{mg} / \mathrm{L})$ & 844 & 680 & 316 \\
\hline $\mathrm{Pb}(\mathrm{mg} / \mathrm{L})$ & $<20.4$ & $<35.5$ & $<3.66$ \\
\hline $\mathrm{Sn}(\mathrm{mg} / \mathrm{L})$ & 22.6 & $<41.8$ & 13.5 \\
\hline Th $(\mathrm{mg} / \mathrm{L})$ & 436 & NM & $<11.8$ \\
\hline $\mathrm{Ti}(\mathrm{mg} / \mathrm{L})$ & 6.56 & 10.4 & 9.77 \\
\hline $\mathrm{U}(\mathrm{mg} / \mathrm{L})$ & 458 & $<737$ & $<27.6$ \\
\hline $\mathrm{Zn}(\mathrm{mg} / \mathrm{L})$ & 38.7 & 28.9 & 4.63 \\
\hline $\mathrm{Zr}(\mathrm{mg} / \mathrm{L})$ & $<0.235$ & $<10.8$ & $2930^{\ddagger}$ \\
\hline \multicolumn{4}{|c|}{$\begin{array}{l}\text { ICP-ES uncertainty }= \pm 10 \% \\
{ }^{*} \text { Assuming } 100 \% \text { dissolution. } \\
\text { Including K from starting solution }(0.2 \mathrm{M} \mathrm{KF}) \\
\text { 'Batch chemical used for fusion. }\end{array}$} \\
\hline
\end{tabular}

Table 3-3. Other Data for Sample 10-16 (Post Dissolution).

\begin{tabular}{||c|c|c|c||}
\hline Analyte & LIMS \# & Method & $\begin{array}{c}\text { 4 hour } \\
\text { Measured (\% unc.) }\end{array}$ \\
\hline $\mathrm{Cl}^{-}(\mu \mathrm{g} / \mathrm{mL})$ & 300282332 & IC & $2770(10)$ \\
\hline $\mathrm{F}^{-}(\mu \mathrm{g} / \mathrm{mL})$ & 300282332 & IC & $3690(10)$ \\
\hline $\mathrm{SO}_{4}^{2-}(\mu \mathrm{g} / \mathrm{mL})$ & 300282332 & IC & $287(10)$ \\
\hline $\mathrm{NO}_{3}^{-}(\mu \mathrm{g} / \mathrm{mL})$ & 300282332 & IC & $730000(10)$ \\
\hline Free $\mathrm{H}^{+}(\mathrm{M})$ & 300282333 & Free Acid & $10.645(10)$ \\
\hline Total H $\mathrm{H}^{+}(\mathrm{M})$ & 300282333 & Total Acid & $11.6(10)$ \\
\hline
\end{tabular}

\subsubsection{Dissolver Off-Gas Data}

Table 3-4 contains the gas generation data. A significant amount of gas was generated during the first 30 minutes at $108{ }^{\circ} \mathrm{C}$. The gas was brownish which implies the presence of nitrogen dioxide $\left(\mathrm{NO}_{2}\right)$. Analysis of the gas sample indicated air had leaked into the dissolver head space or sample bulb after the argon purge. After the first 30 minutes, no noticeable gas was produced. 
SRNL-STI-2011-00222

Revision 0

Table 3-4. Gas Generation Data for 10-16 Dissolution.

\begin{tabular}{|c|c|c|c|c||}
\hline Time at $108^{\circ} \mathrm{C}(\mathrm{min})$ & Volume (mL) & $\begin{array}{r}\mathrm{H}_{2} \text { vol \% } \\
(\% \text { Unc. })\end{array}$ & $\begin{array}{c}\mathrm{N}_{2} \text { vol \% } \\
(\% \text { Unc. })\end{array}$ & $\begin{array}{c}\mathrm{O}_{2} \text { vol \% } \\
(\% \text { Unc. })\end{array}$ \\
\hline $0-30$ & 450 & $<0.1$ & $78(10)$ & $21(10)$ \\
\hline
\end{tabular}

\subsubsection{Residual Solids}

After the initial 4-hour dissolution for Sample 10-16, there was $0.750 \mathrm{~g} \mathrm{(9.88} \mathrm{wt} \mathrm{\% )} \mathrm{of} \mathrm{residue}$ remaining. A portion of the residue $(0.4489 \mathrm{~g})$ was fused with $\mathrm{Na}_{2} \mathrm{O}_{2}$ and dissolved in $4 \mathrm{M} \mathrm{HNO}_{3}$. The resulting solution $(43 \mathrm{~mL})$ was analyzed using gamma spectroscopy, ICP-MS, and ICP-ES. Based on the gamma results, the dissolved $\mathrm{Na}_{2} \mathrm{O}_{2}$ fusion product contained $2.41 \mathrm{~g} / \mathrm{L}$ total $\mathrm{Pu}$. The ICP-MS results indicated a total $\mathrm{Pu}$ concentration of $2.82 \mathrm{~g} / \mathrm{L}$. From these results, it was determined that $0.17 \mathrm{~g}$ (gamma) - $0.20 \mathrm{~g}$ (ICP-MS) of Pu remained in the residue, and $3.09 \mathrm{~g}$ (gamma) $-3.21 \mathrm{~g}$ (ICP-MS) Pu dissolved into solution, meaning $\sim 5.31 \%-5.95 \%$ of the $\mathrm{Pu}$ remained in the residue after dissolution.

The ICP-MS and ICP-ES analyses of the residue also showed significant quantities tungsten (W, $763 \mathrm{mg} / \mathrm{L})$; moderate quantities $(221-348 \mathrm{mg} / \mathrm{L})$ of chromium $(\mathrm{Cr})$, magnesium $(\mathrm{Mg})$, nickel $(\mathrm{Ni})$, and tantalum (Ta); along with even lesser amounts $(<140 \mathrm{mg} / \mathrm{L})$ of aluminum $(\mathrm{Al})$, calcium $(\mathrm{Ca})$, iron $(\mathrm{Fe})$, potassium $(\mathrm{K})$, and tin $(\mathrm{Sn})$. Data for boron $(\mathrm{B})$ and silicon $(\mathrm{Si})$ are omitted as their presence can be attributed to the use of glass sample vials. Sodium (Na) and $\mathrm{Zr}$ are also omitted from Table 3-6 as their presence is due to the addition of $\mathrm{Na}_{2} \mathrm{O}_{2}$ for the fusion and the use of a $\mathrm{Zr}$ crucible, respectively. Elements present at below $0.1 \mathrm{wt} \%$ were also omitted from Table 3-6 (see Table 3-6 for concentration data).

Table 3-5. Concentration Data from Residue Dissolution using $\mathrm{Na}_{2} \mathrm{O}_{2}$ Fusion.

\begin{tabular}{||c|c|c|c||}
\hline Analyte & Method & mg/L (\% unc) & wt \% (\% unc) \\
\hline${ }^{239} \mathrm{Pu}$ & gamma & $2260(5)$ & $21.7(5)$ \\
\hline${ }^{239} \mathrm{Pu}$ & ICP-MS & $2650(20)$ & $25.4(20)$ \\
\hline $\mathrm{Al}$ & ICP-ES & $139(10.1)$ & $1.33(10.1)$ \\
\hline $\mathrm{Ca}$ & ICP-ES & $104(10)$ & $1.00(10)$ \\
\hline $\mathrm{Cr}$ & ICP-ES & $338(10)$ & $3.24(10)$ \\
\hline $\mathrm{Fe}$ & ICP-ES & $136(10)$ & $1.30(10)$ \\
\hline $\mathrm{K}$ & ICP-ES & $139(10)$ & $1.33(10)$ \\
\hline $\mathrm{Mg}$ & ICP-ES & $221(10)$ & $2.12(10)$ \\
\hline $\mathrm{Ni}$ & ICP-ES & $316(10)$ & $3.03(10)$ \\
\hline $\mathrm{Sn}$ & ICP-ES & $13.5(10.6)$ & $0.13(10.6)$ \\
\hline $\mathrm{Ta}$ & ICP-MS & $348(20)$ & $3.33(20)$ \\
\hline $\mathrm{W}$ & ICP-MS & $763(20)$ & $7.31(20)$ \\
\hline \hline
\end{tabular}

\subsection{Discussion}

The Pu dissolution results for sample 10-16 (from Table 3-1) are graphed in Figure 1. The error bars show the analytical uncertainties of $20 \%$ and $5 \%$, for ICP-MS and gamma spectroscopy, respectively. The flowsheet targeted a ${ }^{239} \mathrm{Pu}$ Eq. concentration of $40 \mathrm{~g} / \mathrm{L}$. Both the gamma and ICP-MS data indicate that the majority of the sample dissolved rapidly, reaching ${ }^{239} \mathrm{Pu}$ Eq. concentration of $26.1 \mathrm{~g} / \mathrm{L}$ (gamma) $-27.8 \mathrm{~g} / \mathrm{L}$ (ICP-MS) after 1 hour. There is little change in the $\mathrm{Pu}$ concentration through the next two sampling events; however, an increase in concentration is seen in the 4-hour sample. The ${ }^{239} \mathrm{Pu}$ Eq. concentration after 4 hours of dissolution was measured to be $32.5 \mathrm{~g} / \mathrm{L}$ (gamma) - $33.7 \mathrm{~g} / \mathrm{L}$ (ICP-MS). This data indicates that the full 4 hours of dissolution is necessary to achieve sufficient dissolution. 


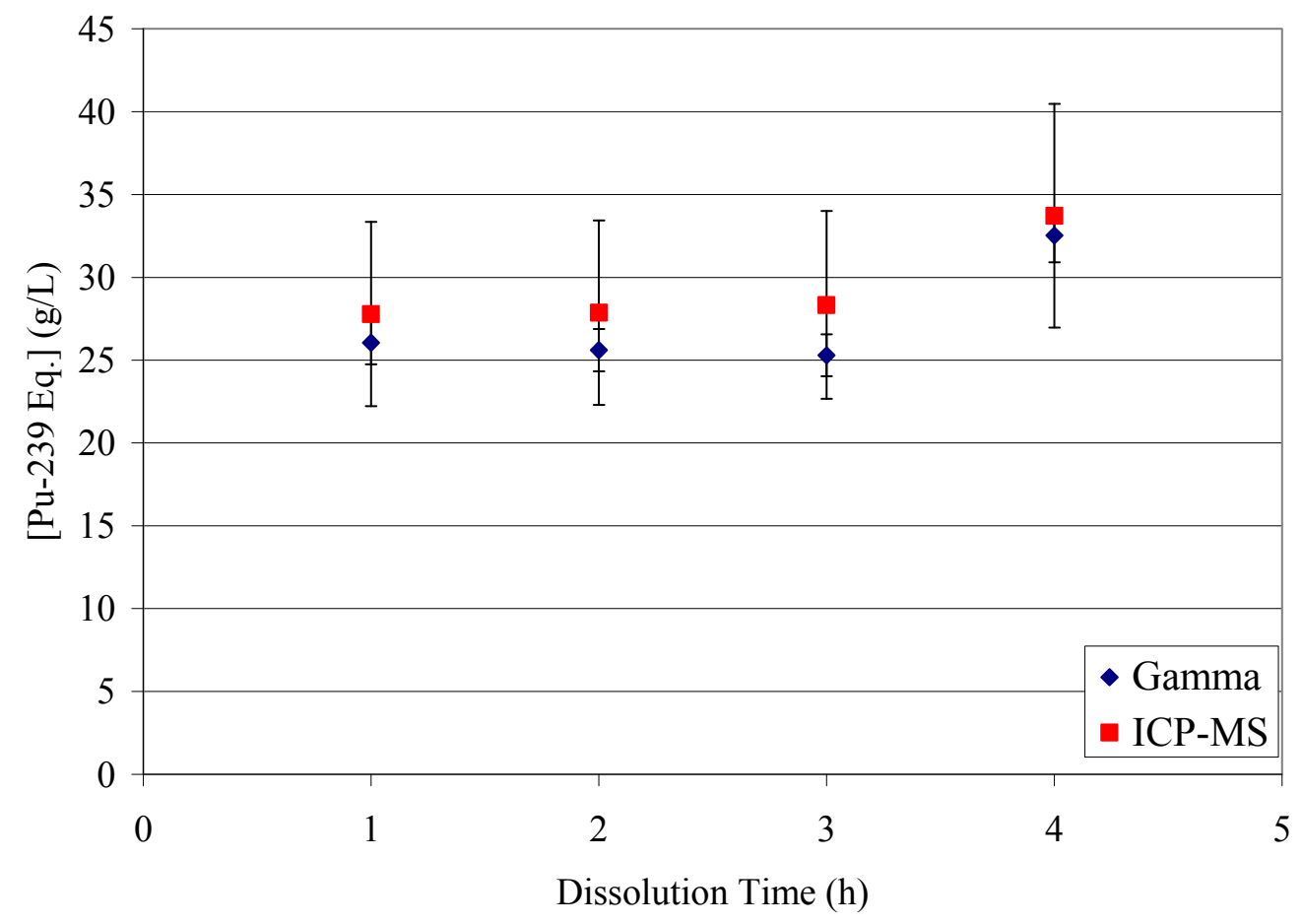

Figure 1. Pu Dissolution Data for 10-16.

The ICP-ES data for potassium $\left(\mathrm{K}^{+}\right)$in Sample 10-16 showed a concentration of $13.1 \mathrm{~g} / \mathrm{L}$, or $0.335 \mathrm{M}$. This value is about $102 \%$ of the calculated value combining the $\mathrm{K}^{+}$in the dissolver solution $(0.2 \mathrm{M}, 7.82 \mathrm{~g} / \mathrm{L})$ and the amount of $\mathrm{K}^{+}$measured in the sample from the $3013 \mathrm{DE}$ Surveillance program $(65.25 \mathrm{mg} / \mathrm{g})$. The calculated concentration is $12.8 \mathrm{~g} / \mathrm{L}$.

Prompt gamma analysis of sample 10-16 revealed $9.86 \mathrm{wt} \% \mathrm{Cl}^{-}$and during the DE Surveillance program analyses, $146,500 \mu \mathrm{g} / \mathrm{g} \mathrm{Cl}^{-}(14.65 \mathrm{wt} \%)$ were detected in this material. After 4 hours of dissolution the $\mathrm{Cl}^{-}$concentration of the solution was $2,770 \mu \mathrm{g} / \mathrm{mL}$. This corresponds to 32,800 $\mu \mathrm{g} / \mathrm{g}$ of sample dissolved (3.28 $\mathrm{wt} \%$ ). This value is only $33 \%$ of the prompt gamma result and $22 \%$ of the value from the DE program. However, the flowsheet test is not designed to provide a quantitative measurement of the amount of $\mathrm{Cl}^{-}$contained in the initial sample, and a low $\mathrm{Cl}^{-}$value is expected due to the formation of volatile $\mathrm{Cl}$ containing species, such as chlorine gas $\left(\mathrm{Cl}_{2}\right)$ and nitrosyl chloride $(\mathrm{ClNO})$, in $12 \mathrm{M} \mathrm{HNO}_{3}{ }^{[9]}$ The $\mathrm{F}^{-}$content $(3,690 \mu \mathrm{g} / \mathrm{mL})$ corresponds to $0.194 \mathrm{M}$ and with an uncertainty of $10 \%$ corresponds to the expected value of the starting solution, $0.20 \mathrm{M}$.

The only other significant dissolved metals detected in the dissolver solution were $\mathrm{K}, \mathrm{Mg}, \mathrm{Na}$, and $\mathrm{Ni}$. The presence of $\mathrm{K}, \mathrm{Na}$, and $\mathrm{Ni}$ are consistent with the XRD studies performed as part of the DE Surveillance program, which detected $\mathrm{NiO}, \mathrm{KCl}$, and $\mathrm{NaCl}$. Small amounts $(<1 \mathrm{wt} \%)$ of several other elements were also detected including $\mathrm{Al}$, barium $(\mathrm{Ba})$, beryllium $(\mathrm{Be}), \mathrm{Ca}, \mathrm{Cd}, \mathrm{Cr}$, $\mathrm{Cu}, \mathrm{Fe}, \mathrm{Mn}, \mathrm{Sn}$, thorium (Th), Ti, and $\mathrm{Zn}$. B and Si were excluded as their presence can be attributed to the use of a glass dissolver vessel and glass sample vials. In general, the ICP-ES data agreed with the results of the 3013 DE Surveillance Program (Table 3-2), with the exception of Al, which was significantly higher in the dissolver solution compared to the $3013 \mathrm{DE}$ results. The ICP-ES values were $562 \%$ for $\mathrm{Al}, 119 \%$ for $\mathrm{Be}, 89.9 \%$ for $\mathrm{Ca}, 100 \%$ for $\mathrm{Cr}, 106 \%$ for $\mathrm{Fe}$, 
$102 \%$ for $\mathrm{K}, 114 \%$ for $\mathrm{Mg}, 138 \%$ for $\mathrm{Mn}, 98.8 \%$ for $\mathrm{Na}, 124 \%$ for $\mathrm{Ni}, 63 \%$ for $\mathrm{Ti}$, and $134 \%$ for Zn compared to the 3013 DE Surveillance values.

The sample data for the residual solids collected after the first filtration are presented in Table 3-6. The mass of insoluble residue recovered subsequent to the dissolution of Sample 10-16 was equivalent to $9.88 \mathrm{wt} \%$ of the starting material, with a $\mathrm{Pu}$ content corresponding to 5.31 $5.95 \mathrm{wt} \%$ of the $\mathrm{Pu}$ present in the starting material. The other primary elements in the residue were $\mathrm{W}, \mathrm{Ta}, \mathrm{Cr}$, and Ni.

Table 3-6. Summary of Residue Data from Sample 10-16.

\begin{tabular}{|c|c|c|c|c|}
\hline \hline Sample & $\begin{array}{c}\text { Residue } \\
(\text { wt \%) }\end{array}$ & $\begin{array}{c}\text { Residue } \\
(\% \mathrm{Pu})\end{array}$ & $\begin{array}{c}\text { wt \% of Initial } \\
\mathrm{Pu} \text { In Residue }\end{array}$ & $\begin{array}{c}\text { Major Elements in } \\
\text { the Residue }\end{array}$ \\
\hline $10-16$ & 9.88 & $21.7-25.4$ & $5.31-5.95$ & $\mathrm{Pu}, \mathrm{W}, \mathrm{Ta}, \mathrm{Cr}, \mathrm{Ni}$ \\
\hline
\end{tabular}

The dissolver solution was filtered three times. The first filtration occurred after 4 hours of dissolution and cooling of the dissolver solution to approximately $50{ }^{\circ} \mathrm{C}$. The solution filtered readily and $0.750 \mathrm{~g}$ of residue was collected. The second filtration occurred 30 minutes after the addition of sufficient 2.1 M ANN solution to attain a 3:1 Al:F ratio, and the filtration was rapid, completing in 55 seconds. The solution was filtered a third time 24 hours after the addition of 2.1 M ANN and the solution filtered about 6 times slower and was complete within 6 minutes. The empirical data indicate that the ANN solubility at room temperature was likely exceeded. Similar behavior has been observed in earlier flowsheet studies. ${ }^{[10]}$

\subsection{Conclusions}

Flowsheet testing was performed on 3013 DE Sample 10-16 using $12 \mathrm{M} \mathrm{HNO}_{3}$ and $0.2 \mathrm{M} \mathrm{KF}$ at $108{ }^{\circ} \mathrm{C}$ for 4 hours with an initial charge of $40 \mathrm{~g} / \mathrm{L}{ }^{239} \mathrm{Pu}$ Eq. Sample information is listed in Table 1-2. Based on XRD analysis of the starting material (see Table 1-2), it appears that the Pu present in this material was present as $\mathrm{PuO}_{2}$. The results of the flowsheet study show that $26.1 \mathrm{~g} / \mathrm{L}{ }^{239} \mathrm{Pu}$ Eq. (gamma) dissolved after the first hour at temperature and that the $\mathrm{Pu}$ concentration remained essentially constant through 3 hours, with a slight increase in ${ }^{239} \mathrm{Pu}$ Eq. concentration at the final $(4 \mathrm{~h})$ time point, reaching a final ${ }^{239} \mathrm{Pu}$ Eq. concentration of $32.5 \mathrm{~g} / \mathrm{L}$ (gamma) $-33.7 \mathrm{~g} / \mathrm{L}$ (ICP-MS). A 4-hour dissolution time at a temperature of $108{ }^{\circ} \mathrm{C}$ and a $\mathrm{KF}$ concentration of $0.2 \mathrm{M}$ is acceptable for performance of this flowsheet. If the target temperature cannot be reached, results of earlier tests show that dissolution at $103{ }^{\circ} \mathrm{C}$ in $12 \mathrm{M} \mathrm{HNO}_{3} / 0.2 \mathrm{M}$ $\mathrm{KF}$ for 8 hours is an acceptable alternative. ${ }^{[1]}$

Prompt gamma analysis of Sample 10-16 measured $9.86 \mathrm{wt} \% \mathrm{Cl}^{-}$, and in the DE Surveillance program, leaching studies produced 146,500 $\mathrm{g} \mathrm{Cl}^{-} / \mathrm{g}$ of sample (or $14.65 \mathrm{wt} \%$ ). The sample was not washed prior to dissolution and, after 4 hours of dissolution, $2,770 \mu \mathrm{g} / \mathrm{mL} \mathrm{Cl}^{-}(3.28 \mathrm{wt} \%)$ was present in the solution. Other metallic elements detected in significant quantities included $\mathrm{K}$, $\mathrm{Mg}, \mathrm{Na}$, and $\mathrm{Ni}$. In general, the concentrations of all elements measured in solution were in agreement with what was expected based upon data from the 3013 DE Program (Table 1-2), with the exception of Al. The major elements present in the dissolver product solution are listed in Table 4-1. Elements attributed to the dissolution of the experimental glassware (B and $\mathrm{Si}$ ) were omitted. A minimum concentration of $0.01 \mathrm{M}$ was selected as the basis for inclusion in the table. 
Table 4-1. Elements/Anions in DE Sample 10-16 Dissolver Product Solution.

\begin{tabular}{|c|c|c|c|c|c|c|c|c|}
\hline Analyte & $\mathbf{B e}^{*}$ & $\mathrm{Ca}^{*}$ & $\mathrm{Cl}^{\dagger}$ & $\mathbf{K}^{* \#}$ & $\mathrm{Mg}^{*}$ & $\mathrm{Na}^{*}$ & $\mathrm{Ni}^{*}$ & $\mathbf{P u}{ }^{\wedge}$ \\
\hline Concentration (M) & 0.013 & 0.010 & 0.078 & 0.135 & 0.046 & 0.138 & 0.014 & 0.141 \\
\hline $\begin{array}{c}\text { Concentration } \\
\text { ( } \mu \mathrm{g} / \mathrm{g} \text { dissolved material) }\end{array}$ & 1,620 & 5,500 & 34,300 & 72,600 & 15,300 & 43,700 & 11,600 & 469,000 \\
\hline \multicolumn{9}{|c|}{$\begin{array}{l}\text { From ICP-ES data } \\
\text { From IC anion data } \\
\text { A Subtracting amount attributed to starting solution (KF) } \\
\text { From ICP-MS data }\end{array}$} \\
\hline
\end{tabular}

Upon cooling to $\sim 50{ }^{\circ} \mathrm{C}$, filtration of the dissolver solution occurred readily. Upon ANN addition ( 3 moles of $\mathrm{Al}$ per mole of $\mathrm{F}^{-}$) to the dissolver solution at room temperature, filtration (after a 30 minute delay) was rapid, requiring less than one minute to complete. The rate of this filtration was approximately $130 \mathrm{~mL} / \mathrm{min}$. After storage at ambient temperature 24 hours the solution filtered about 6 times slower, with filtration complete in 6 minutes. This corresponds to a rate of approximately $20 \mathrm{~mL} / \mathrm{min}$.

Table 4-2. Flowsheet Test Summary for DE Sample 10-16.

\begin{tabular}{||c|c||}
\hline Flowsheet Test Conditions & $12 \mathrm{M} \mathrm{HNO}_{3} / 0.20 \mathrm{M} \mathrm{KF}$ for $4 \mathrm{~h}$ at $108^{\circ} \mathrm{C}$ \\
\hline Charge Ratio Tested & $40 \mathrm{~g} \mathrm{Pu} / \mathrm{L}$ \\
\hline Undissolved Solids (UDS) & $9.88 \mathrm{wt} \%$ \\
\hline Predominant Element in UDS & $\mathrm{Pu}$ \\
\hline Minor Elements in UDS & $\mathrm{W}, \mathrm{Ta}, \mathrm{Cr}, \mathrm{Ni}, \mathrm{Mg}$ \\
\hline Initial Pu in UDS & $5.31-5.95 \mathrm{wt} \%$ \\
\hline $\begin{array}{c}\text { Gas Generation (Initial heating and } \\
\text { first 30 min. at temperature) }\end{array}$ & $\sim 60 \mathrm{~mL} / \mathrm{g}$ of sample \\
\hline $\mathbf{H}_{\mathbf{2}}$ in Generated Gas & $<0.12 \mathrm{vol} \%$ \\
\hline
\end{tabular}




\subsection{References}

1. DOE Standard: Stabilization, Packaging, and Storage of Plutonium-Bearing Materials, DOE-STD-3013-2004, U.S. Department of Energy, Washington, DC (2004).

2. R. A. Pierce, J. H. Gray, and M. G. Bronikowski, "Flowsheet Studies for the Dissolution of High Fired Plutonium Dioxide in the Presence of Gadolinium," WSRC-STI-200700673, Rev. 1, July 2008.

3. J. W. Christopher, "Perform Flow Sheet Verification on DE3013 Samples for HBL Dissolution," Technical Task Request NMMD-HTS-2009-3064, Rev. 2, December 9, 2009.

4. M. L. Crowder, "Task Technical and Quality Assurance Plan for Flowsheet Testing including Vacuum Salt Distillation of 3013 DE Materials," SRNL-RP-2010-01669, December 2010.

5. R. A. Pierce, "Effect of Aluminum Nitrate Addition to HB-Line Dissolver Solutions," SRNL-STI-2009-00176, April 2009.

6. Data from 3013 DE Surveillance Program, Filename "R610826-CXRD-RP1.xls" Located on SRNL Results server, August 2010.

7. Data from 3013 DE Surveillance Program, Filename "10DE16_ICP-ES_R610826.xls" Located on SRNL Results server, August 2010.

8. Data from 3013 DE Surveillance Program, Filename "10DE16_IC_R610826.xls" Located on SRNL Results server, August 2010.

9. R. A. Pierce, "FY07 Year-End Report - Chloride to Nitrate Solution Conversion," WSRC-STI-2008-00104, February 2008.

10. R. A. Pierce, "Dissolution of 3013-DE Compounds: Sample 09-11," SRNL-STI-200900814, December 2009.

11. R. A. Pierce, "Adjustment of Dissolution Conditions to Compensate for Reduced Dissolution Temperatures", SRNL-TR-2009-00472, December 2009. 
SRNL-STI-2011-00222

Revision 0

Appendix A 


\section{APPENDIX A: Sample 10-16 Solution Data}

Appendix A.1: Sample 10-16 ICP-MS Data.

Method Uncertainty $=20 \%$

\begin{tabular}{|l|c|c|c|c|c|}
\hline LIMS Sample \# & 300282327 & 300282328 & 300282329 & 300282330 & 300282710 \\
\hline
\end{tabular}

\begin{tabular}{|c|c|c|c|c|c|}
\hline Analyte & $\mathbf{1} \mathbf{h}^{*}$ & $\mathbf{2} \mathbf{h}^{*}$ & $\mathbf{3} \mathbf{h}^{*}$ & $\mathbf{4} \mathbf{h}^{*}$ & Fused Residue \\
\hline
\end{tabular}

\begin{tabular}{l|l|l|l|l|l|}
${ }^{116} \mathrm{Sn}(\mu \mathrm{g} / \mathrm{L})$ & $<3.00 \mathrm{E}+04$ & $<3.00 \mathrm{E}+04$ & $<3.00 \mathrm{E}+04$ & $<3.00 \mathrm{E}+04$ & $1.22 \mathrm{E}+03$
\end{tabular}

\begin{tabular}{l|l|l|l|l|l|l|}
${ }^{118} \mathrm{Sn}(\mu \mathrm{g} / \mathrm{L})$ & $<2.00 \mathrm{E}+04$ & $<2.00 \mathrm{E}+04$ & $<2.00 \mathrm{E}+04$ & $<2.00 \mathrm{E}+04$ & $2.14 \mathrm{E}+03$
\end{tabular}

\begin{tabular}{|l|l|l|l|l|l|}
${ }^{119} \mathrm{Sn}(\mu \mathrm{g} / \mathrm{L})$ & $<2.00 \mathrm{E}+04$ & $<2.00 \mathrm{E}+04$ & $<2.00 \mathrm{E}+04$ & $<2.00 \mathrm{E}+04$ & $1.51 \mathrm{E}+03$ \\
\hline
\end{tabular}

\begin{tabular}{|c|c|c|c|c|c|}
\hline${ }^{120} \mathrm{Sn}(\mu \mathrm{g} / \mathrm{L})$ & $1.11 \mathrm{E}+05$ & $1.17 \mathrm{E}+05$ & $1.21 \mathrm{E}+05$ & $1.42 \mathrm{E}+05$ & $1.45 \mathrm{E}+04$ \\
\hline Total $\mathrm{Sn}(\mathrm{g} / \mathrm{L})^{\dagger}$ & 0.339 & 0.359 & 0.371 & 0.436 & 0.0445 \\
\hline
\end{tabular}

\begin{tabular}{|l|l|l|l|l|l|}
\hline & & & & & \\
\hline${ }^{133} \mathrm{Cs}(\mu \mathrm{g} / \mathrm{L})$ & $2.72 \mathrm{E}+04$ & $3.28 \mathrm{E}+04$ & $3.90 \mathrm{E}+04$ & $2.30 \mathrm{E}+04$ & $<1.00 \mathrm{E}+03$ \\
\hline${ }^{137} \mathrm{Ba}(\mu \mathrm{g})$ & $<2.00 \mathrm{E}+04$ & $<2.00 \mathrm{E}+04$ & $<2.00 \mathrm{E}+04$ & $<2.00 \mathrm{E}+04$ & $1.17 \mathrm{E}+03$ \\
\hline
\end{tabular}

\begin{tabular}{|c|c|c|c|c|c|c|}
\hline${ }^{137} \mathrm{Ba}(\mu \mathrm{g} / \mathrm{L})$ & $<2.00 \mathrm{E}+04$ & $<2.00 \mathrm{E}+04$ & $<2.00 \mathrm{E}+04$ & $<2.00 \mathrm{E}+04$ & $1.17 \mathrm{E}+03$ \\
\hline${ }^{138} \mathrm{Ba}(\mu \mathrm{g} / \mathrm{L})$ & $<2.00 \mathrm{E}+04$ & $<2.00 \mathrm{E}+04$ & $<2.00 \mathrm{E}+04$ & $<2.00 \mathrm{E}+04$ & $5.51 \mathrm{E}+03$ \\
\hline
\end{tabular}

\begin{tabular}{|c|c|c|c|c|c|}
\hline${ }^{176} \mathrm{Hf}(\mu \mathrm{g} / \mathrm{L})$ & $<2.00 \mathrm{E}+04$ & $<2.00 \mathrm{E}+04$ & $<2.00 \mathrm{E}+04$ & $<2.00 \mathrm{E}+04$ & $1.44 \mathrm{E}+03$ \\
\hline
\end{tabular}

\begin{tabular}{|c|c|c|c|c|c|}
\hline${ }^{177} \mathrm{Hf}(\mu \mathrm{g} / \mathrm{L})$ & $<4.00 \mathrm{E}+04$ & $<4.00 \mathrm{E}+04$ & $<4.00 \mathrm{E}+04$ & $<4.00 \mathrm{E}+04$ & $4.96 \mathrm{E}+03$ \\
\hline
\end{tabular}

\begin{tabular}{|c|c|c|c|c|c|c|}
\hline${ }^{178} \mathrm{Hf}(\mu \mathrm{g} / \mathrm{L})$ & $<4.00 \mathrm{E}+04$ & $<4.00 \mathrm{E}+04$ & $<4.00 \mathrm{E}+04$ & $<4.00 \mathrm{E}+04$ & $7.36 \mathrm{E}+03$ \\
\hline${ }^{170} \mathrm{Hf}(\mu \mathrm{g} / \mathrm{L})$ & $<2.00 \mathrm{E}+04$ & $<2.00 \mathrm{E}+04$ & $<2.00 \mathrm{E}+04$ & $<2.00 \mathrm{E}+04$ & $4.06 \mathrm{E}+03$ \\
\hline
\end{tabular}

\begin{tabular}{|c|c|c|c|c|c|}
\hline${ }^{179} \mathrm{Hf}(\mu \mathrm{g} / \mathrm{L})$ & $<2.00 \mathrm{E}+04$ & $<2.00 \mathrm{E}+04$ & $<2.00 \mathrm{E}+04$ & $<2.00 \mathrm{E}+04$ & $4.06 \mathrm{E}+03$ \\
\hline
\end{tabular}

\begin{tabular}{|c|c|c|c|c|c|}
\hline${ }^{180} \mathrm{Hf}(\mu \mathrm{g} / \mathrm{L})$ & $<2.00 \mathrm{E}+04$ & $<2.00 \mathrm{E}+04$ & $<2.00 \mathrm{E}+04$ & $<2.00 \mathrm{E}+04$ & $1.17 \mathrm{E}+04$ \\
\hline
\end{tabular}

\begin{tabular}{|l|l|l|l|l|l|}
${ }^{181} \mathrm{Ta}(\mu \mathrm{g} / \mathrm{L})$ & $4.08 \mathrm{E}+04$ & $2.24 \mathrm{E}+04$ & $3.10 \mathrm{E}+04$ & $<2.00 \mathrm{E}+04$ & $3.48 \mathrm{E}+05$ \\
\hline
\end{tabular}

\begin{tabular}{|c|c|c|c|c|c|}
\hline${ }^{182} \mathrm{~W}(\mu \mathrm{g} / \mathrm{L})$ & $<2.00 \mathrm{E}+04$ & $<2.00 \mathrm{E}+04$ & $<2.00 \mathrm{E}+04$ & $<2.00 \mathrm{E}+04$ & $1.98 \mathrm{E}+05$ \\
\hline${ }^{183} \mathrm{~W}(\mu \mathrm{g} / \mathrm{L})$ & $<2.00 \mathrm{E}+04$ & $<2.00 \mathrm{E}+04$ & $<2.00 \mathrm{E}+04$ & $<2.00 \mathrm{E}+04$ & $1.08 \mathrm{E}+05$ \\
\hline
\end{tabular}

\begin{tabular}{|c|c|c|c|c|c|}
\hline${ }^{183} \mathrm{~W}(\mu \mathrm{g} / \mathrm{L})$ & $<2.00 \mathrm{E}+04$ & $<2.00 \mathrm{E}+04$ & $<2.00 \mathrm{E}+04$ & $<2.00 \mathrm{E}+04$ & $1.08 \mathrm{E}+05$ \\
\hline
\end{tabular}

\begin{tabular}{|c|c|c|c|c|c|}
${ }^{184} \mathrm{~W}(\mu \mathrm{g} / \mathrm{L})$ & $<3.00 \mathrm{E}+04$ & $<3.00 \mathrm{E}+04$ & $<3.00 \mathrm{E}+04$ & $<3.00 \mathrm{E}+04$ & $2.37 \mathrm{E}+05$ \\
\hline${ }^{186} \mathrm{~W}(\mu \mathrm{g} / \mathrm{L})$ & $<2.00 \mathrm{E}+04$ & $<2.00 \mathrm{E}+04$ & $<2.00 \mathrm{E}+04$ & $<2.00 \mathrm{E}+04$ & $2.21 \mathrm{E}+05$
\end{tabular}

\begin{tabular}{|c|c|c|c|c|c|}
${ }^{186} \mathrm{~W}(\mu \mathrm{g} / \mathrm{L})$ & $<2.00 \mathrm{E}+04$ & $<2.00 \mathrm{E}+04$ & $<2.00 \mathrm{E}+04$ & $<2.00 \mathrm{E}+04$ & $2.21 \mathrm{E}+05$ \\
\hline
\end{tabular}

\begin{tabular}{|c|c|c|c|c|c|}
\hline Total W $(\mathrm{g} / \mathrm{L})$ & $<0.0979^{\ddagger}$ & $<0.0979^{\ddagger}$ & $<0.0979^{\ddagger}$ & $<0.0979^{\ddagger}$ & $0.763^{\dagger \dagger}$ \\
\hline
\end{tabular}

\begin{tabular}{|c|c|c|c|c|c|}
\hline & & & & & \\
\hline${ }^{235} \mathrm{U}(\mu \mathrm{g} / \mathrm{L})$ & $6.06 \mathrm{E}+04$ & $7.70 \mathrm{E}+04$ & $7.18 \mathrm{E}+04$ & $7.06 \mathrm{E}+04$ & $4.38 \mathrm{E}+03$ \\
\hline
\end{tabular}

\begin{tabular}{|l|l|l|l|l|l|l|}
\hline${ }^{238} \mathrm{U}(\mu \mathrm{g} / \mathrm{L})$ & $<1.10 \mathrm{E}+05$ & $<1.10 \mathrm{E}+05$ & $<1.10 \mathrm{E}+05$ & $<1.10 \mathrm{E}+05$ & $4.02 \mathrm{E}+03$ \\
\hline & & & & & \\
\hline
\end{tabular}

\begin{tabular}{|c|c|c|c|c|c|}
\hline${ }^{239} \mathrm{Pu}(\mu \mathrm{g} / \mathrm{L})$ & $2.62 \mathrm{E}+07$ & $2.62 \mathrm{E}+07$ & $2.66 \mathrm{E}+07$ & $3.18 \mathrm{E}+07$ & $2.65 \mathrm{E}+06$ \\
\hline${ }^{240} \mathrm{Pu}(\mu \mathrm{g} / \mathrm{L})$ & $1.54 \mathrm{E}+06$ & $1.62 \mathrm{E}+06$ & $1.69 \mathrm{E}+06$ & $1.88 \mathrm{E}+06$ & $1.73 \mathrm{E}+05$ \\
\hline Total $\mathrm{Pu}(\mathrm{g} / \mathrm{L})$ & 27.7 & 27.8 & 28.3 & 33.7 & 2.82 \\
\hline \begin{tabular}{c}
$\%{ }^{239} \mathrm{Pu}$ \\
\hline $\begin{array}{c}{ }^{241} \mathrm{Pu}+{ }^{241} \\
(\mu \mathrm{g} / \mathrm{Lm})\end{array}$
\end{tabular} & $94.4 \%$ & $94.2 \%$ & $94.0 \%$ & $94.4 \%$ & $93.9 \%$ \\
\hline $\begin{array}{c}{ }^{242} \mathrm{Pu}+{ }^{242} \mathrm{Am} \\
(\mu \mathrm{g} / \mathrm{L})\end{array}$ & $<4.00 \mathrm{E}+04$ & $9.04 \mathrm{E}+04$ & $1.06 \mathrm{E}+05$ & $1.00 \mathrm{E}+05$ & $1.02 \mathrm{E}+04$ \\
\hline
\end{tabular}

* Accounting for a dilution factor of 2.

${ }^{\dagger}$ Calculated using the natural abundance of ${ }^{120} \mathrm{Sn}$.

* Calculated using the natural abundance of ${ }^{184} \mathrm{~W}$.

$\because$ Calculated using the natural abundances of all four $\mathrm{W}$ isotopes. 
SRNL-STI-2011-00222

Revision 0

Appendix A.2: Sample 10-16 Gamma Spectroscopy Data.

\begin{tabular}{|c|c|c|c|c|c|}
\hline LIMS Sample \# & 300282323 & 300282324 & 300282325 & 300282326 & 300282709 \\
\hline Analyte & $1 \mathrm{~h}^{*}$ & $2 h^{*}$ & $3 \mathbf{h} *$ & $4 h^{*}$ & Fused Residue \\
\hline${ }^{239} \mathrm{Pu}(\mathrm{dpm} / \mathrm{mL})$ & $3.38 \mathrm{E}+09$ & $3.32 \mathrm{E}+09$ & $3.28 \mathrm{E}+09$ & $4.22 \mathrm{E}+09$ & $3.12 \mathrm{E}+08$ \\
\hline 1 Sigma $\%$ Unc. & 5.00 & 5.27 & 5.00 & 5.00 & 5.00 \\
\hline${ }^{241} \mathrm{Am}(\mathrm{dpm} / \mathrm{mL})$ & $5.06 \mathrm{E}+08$ & $5.08 \mathrm{E}+08$ & $5.08 \mathrm{E}+08$ & $6.56 \mathrm{E}+08$ & $6.04 \mathrm{E}+07$ \\
\hline 1 Sigma $\%$ Unc. & 5.00 & 5.00 & 5.00 & 5.00 & 5.00 \\
\hline${ }^{239} \mathrm{Pu}(\mathrm{g} / \mathrm{L})$ & 24.5 & 24.1 & 23.8 & 30.6 & 2.26 \\
\hline${ }^{241} \mathrm{Am}(\mathrm{g} / \mathrm{L})$ & 0.0664 & 0.0667 & 0.0667 & 0.0861 & 0.00793 \\
\hline
\end{tabular}




\section{Distribution:}
A. B. Barnes, 999-W
D. A. Crowley, 773-43A
S. D. Fink, 773-A
B. J. Giddings, 786-5A
C. C. Herman, 999-W
S. L. Marra, 773-A
A. M. Murray, 703-H
F. M. Pennebaker, 773-42A
G. F. Kessinger, 773-A
R. A. Pierce, 773-A
A. E. Visser, 773-A
M. L. Crowder, 773-A
S. A. Thomas, 703-46A

W. E. Harris, 704-2H

J. B. Schaade, 704-2H

G. J. Zachman, 225-7H

K. J. Gallahue, 221-HBL

K. P. Burrows, 704-2H

J. W. Christopher, 704-2H

A. T. Masterson, 704-2H

M. T. Pelc, 704-2H

T. D. Woodsmall, 704-2H

HBLSTE, 221-HBL 